\title{
The argan oil project: going from utopia to reality in 20 years
}

\author{
Zoubida Charrouf ${ }^{1, *}$ and Dominique Guillaume ${ }^{2}$ \\ ${ }^{1}$ Laboratoire de Chimie des Plantes et de Synthèse Organique et Bioorganique, Faculté des Sciences, Université Mohammed V, \\ BP 1014, Rabat, Morocco \\ 2 CNRS-UMR7312, UFR Med-Pharm., Chimie Thérapeutique, 51 rue Cognacq-Jay, 51100 Reims, France
}

Received 9 November 2017 - Accepted 22 January 2018

\begin{abstract}
The "argan oil project" is nowadays considered as an economic success that harmoniously combined sustainable development, integrated research-action and socio-economic progress. Actually, it was a long battle whose main stages are presented here. The main stages of the argan oil project include a detailed chemical study of argan oil in order to certify argan oil quality and establish an official quality norm and obtain a geographic indication, pharmacological analyses to certify cosmetic argan oil safety, and finally a strong desire to develop Moroccan rural areas by implementing women's cooperatives and easing the women's access to education.
\end{abstract}

Keywords: argan oil / edible oil / cosmetic oil / Morocco / field research

\begin{abstract}
Résumé - Le projet arganier : 20 ans pour passer de l'utopie à la réalité.. Le "projet arganier » est considéré comme un succès économique qui a mélangé harmonieusement le développement durable, la recherche-action intégrée et le progrès économique et social. En réalité, ce fut une longue bataille dont les principales étapes sont présentées ci-après. Les étapes principales du projet huile d'argan comprennent une étude chimique détaillée de l'huile d'argan pour certifier sa qualité, établir une norme officielle et obtenir une indication géographique protégée, des analyses pharmacologiques certifiant la sécurité de l'huile d'argan et enfin un fort désir de développer les zones rurales marocaines en mettant en place des coopératives de femmes et en facilitant l'accès des femmes à l'éducation.
\end{abstract}

Mots clés : huile d'argan / huile alimentaire / huile cosmétique / Maroc / recherche-action

\section{History}

Argan oil is frequently said to have been used by the Phoenicians settled along the North African Coast, at the dawn of the first millennium BCE. Consequently, it is difficult to simultaneously comprehensively and briefly summarized argan oil global history. Therefore, we will mainly concentrate on the modern-time argan oil history that is currently considered to have begun with the first report of the description of the chemical composition of argan oil in the early 1970s (Berrada, 1972). In this early paper, argan oil was depicted as a valuable South-Western Moroccan food, unsaturated fatty acid-, stigmasterol-, and tocopherol-rich, and exclusively prepared on a family-scale for a household use. Indeed, as difficult as it may seem to believe, even in the 1970s, argan oil was virtually not known in Northern Morocco, not to say out of Morocco. It was actually almost exclusively known in a triangular part of Morocco, located South of the High Atlas and

*Correspondence: zcharrouf@yahoo.fr
North of the Anti Atlas. This area that slightly surpasses a large western-part of the Souss Massa administrative region has as major cities Agadir, Essaouira, and Tiznit on its West seaboard, and Taroudant on its East side. Such a geographically-limited fame was the direct result of the natural very limited argan tree distribution, the tree from the fruit of which argan oil is prepared, and also from the limited preservation ability of argan oil that, at that time, prohibited its large distribution.

The argan tree (Argania spinosa (L.) Skeels) is an 80million-year-old relic tree species that anciently covered large areas in Northern Africa from where it nearly went extinct during Quaternary glaciations with the exception of the Souss valley where temperate ocean climate conditions and mountain-provided wind protection allowed optimum conditions for its survival (Kenny and De Zborowski, 2007). Today, the argan tree grows mainly in the Sous Massa region, a semi-arid and arid area, where the tree covers an area estimated to 870000 ha even though a recent estimation performed by remote sensing led to a superficy of about 1000000 ha (Mounir et al., 2015). This superficy was much larger one century ago but for a long time argan tree has defied 
domestication. In addition, a slow rate of growth associated with a prolonged national failing agricultural policy encouraging deforestation, and an over use of argan tree as fuel or forage have driven the argan tree into the group of the possibly endangered species. Because argan tree acted as a green curtain protecting a large part of Southern Morocco against the encroaching Sahara, argan tree slow disappearance became considered as an ecological disaster. Full awareness of the problems came in 1998 when the specific landscape of the Argan forest was designated a UNESCO biosphere reserve.

This is when argan oil experienced its second birth with the start of an ambitious and multidisciplinary project intimately mixing academic and industrial interests in the fields of organic and analytical chemistry, agronomy, sustainable development, ecology, economy, and social sciences. This project that is frequently simply referred to as the "argan oil project"(AOP) began in 1985. The underlying idea of the project was based on the transformation of an environmental problem into an economic opportunity that would have to simultaneously and inevitably promote the preservation of the argan forest. The idea of the AOP was based on a simple observation: the rural population of the argan forest was not considering argan treerelated activities as an agricultural activity. Hence, the rural population was not preserving the tree, as it was done for example for the olive tree for example. Consequently, the argan tree was gradually declining. Such disinterest was motivated by the idea that the argan tree traditionally represented a low source of income or any, its main agrarian function was to shade cattle and possibly some domestic crops. If argan tree cultivation could be regarded as a rewarding activity, meaning that argan tree (or its side products) could become a permanent source of revenue, local dwellers would protect the tree and even replant new ones. The battle against desertification could be won and population could get wealthier.

After some trial, the easiest-to-promote production of the argan tree appeared to be argan oil, the Phoenician-known produce. Indeed, its trading could easily represent the lookedafter income source that would sparkle the necessary virtuous circle to safeguard the argan tree/forest. To succeed, the AOP had to overcome five major pitfalls:

- argan oil production had to grow from family-scale to industrial-scale;

- the argan oil composition had to be unambiguously established to avoid adulteration;

- argan oil quality had to be certified;

- the problem of argan oil low preservation had to be surmounted;

- for the project to sustainable on the long-term, argan oil market had to be decupled meaning that the virtues of the only-locally known argan oil had to become known well beyond the borders of Morocco.

Because the project was run in a highly conservative rural context, all changes had to respect the traditional values of the concerned populations while enabling emancipation of rural women. This is why reading classes were offered to women participating to the project, as well as more elaborated formations such as word processing classes or management classes.

\section{Argan oil}

Argan oil is a copper-colored edible oil which presents a slight hazelnut taste and nutty flavor. It is prepared for the roasted kernels of Argani aspinosa fruit. Whereas traditional argan oil was almost exclusively intended for culinary purposes, its hair- and skin-protective properties were known in folk medicine. One of the first initiatives of the argan oil project was to clearly separate edible from cosmetic argan oil. Such distinction was aimed at positioning edible argan oil in the gourmet-oil segment whereas odorless and tasteless cosmetic argan oil, with its slightly gold-color, could meet the requirements of the cosmetic industry. Taste/odor elimination was simply achieved by the use of fresh kernels (cosmetic oil) in place of roasted kernels (edible oil) in the preparation process.

Argan oil is the main lipid source of the Amazigh diet (Charrouf and Guillaume, 2010), it is traditionally prepared by women. Argan oil preparation is a tedious seven-step (fruit picking, fruit peeling, nut cracking, kernel roasting, kernel grinding, dough malaxing, and oil collection) process whose efficiency is low. From $100 \mathrm{~kg}$ of dried fruit, only $2-2.5 \mathrm{~L}$ of oil can be obtained after $58 \mathrm{~h}$ of work for an isolated woman. One of the first major achievements of the AOP was to rapidly permit an increase of the process efficiency by mechanization of the oil collection step, and to a lesser extent of the roasting step. Indeed, replacement of the hand-made dough kneading step by endless screws, was without doubt an important milestone that reduces the hassle of the extraction process and allowed to collect $3 \mathrm{~L}$ of oil from $100 \mathrm{~kg}$ of dried fruit after only $30 \mathrm{~h}$ of isolated woman work. Use of endless screws also permitted to eliminate the introduction of water (traditionally necessary to obtain the dough) in the process. Consequently, endless screw use suppressed bacteriological complications caused by the presence of an aqueous media and responsible of traditional argan oil low preservation properties. It also allowed the production of an oil of high, standardized, and reproducible quality. A full technical description of the early argan oil preparative process and of its successive improvements can be found in the literature (Guillaume and Charrouf, 2016). As an ultimate consequence, this improved process paved the way to design and build small production units, independent but unit in a large global structure, and all placed under the responsibility of women. Highly importantly, it could also be rapidly demonstrated that introduction of mechanization in the argan oil preparative process had no negative impact on argan oil physico-chemical properties (Hilali et al., 2005). This precious finding had two impacts: first, argan oil could join olive oil as a prized member of the "cold press oil privilege club" and, second, it could be assessed that the new technology preserved all the known benefits of the traditionally prepared argan oil. Nowadays, argan oil is still prepared following the mechanized process even though in some places highly efficient hydraulic presses have replaced endless crews. Note worthily, the cosmetic industry frequently adds a physical refining step to remove residual gums and/or phospholipids and for deodorization purposes. As a consequence of these efficient preparative improvements, argan oil exports have boomed from 1 ton in 1996, a time when argan fruit was little picked up, to 1387 tons in 2016, positively impacting the Moroccan commercial balance. 
A lot of traditionally known benefits of argan oil follow from its physico-chemical properties. Edible and cosmetic argan oil present the same fatty acid composition and are unsaturated fatty acid rich. Argan oil contains 43 to $49 \%$ of oleic acid, a mono unsaturated fatty acid, and 29.3 to $36 \%$ of linoleic acid, a poly-unsaturated fatty acid. Saturated fatty acids constitute only 16 to $20 \%$ of argan oil composition (palmitic acid: $11.5-15 \%$ and stearic acid 4.3-7.2\%) (Norme SNIMA, 2003). Argan oil also contains 600 to $900 \mathrm{mg} / \mathrm{kg}$ of tocopherols, 81 to $92 \%$ of which being $\gamma$-tocopherol. $\alpha-, \beta-$, and $\delta$-tocopherols represent 2.4 to $6.5 \%, 0.1$ to $0.3 \%$, and 6.2 to $12.8 \%$ of the total tocopherols, respectively (Norme SNIMA, 2003). Tocopherols possess a strong antioxidant capacity and a powerful anti-free-radical ability. Together with tocopherols, argan oil contains other antioxidant molecules such as $\mathrm{CoQ}_{10}$ $(20 \mathrm{mg} / \mathrm{kg}$ of oil) and melatonin $(60 \mathrm{ng} / \mathrm{kg}$ of oil). However, argan oil does not contain $\mathrm{CoQ}_{9}$ (Venegas et al., 2011). Argan oil content also includes up to $220 \mathrm{mg} / 100 \mathrm{~g}$ of phytosterols; the two main of which being schottenol (44-49\%), and spinasterol (34-44\%) (Norme SNIMA, 2003). Minute variations in chemical composition have been observed between edible and cosmetic. Indeed, if kernel roasting induces no change in fatty acid or tocopherol composition, the two most important families of compounds on a pharmacological stand point (Harhar et al., 2011), it induces the formation of odorants responsible for the characteristic taste or edible argan oil (Charrouf et al., 2006) an increase of polyphenols and phospholipids.

Adulteration of argan oil is an old but complex problem. For years, argan forest dwellers have sold for a few dirhams alduterated argan oil in plastic bottles to tourists along the Moroccan roads. During that time, the alleged argan oil was frequently exclusively or majoritarily a cheap edible oil (most often sunflower) colored by addition of a small amount of paprika or turmeric powder. With the production of mechanized argan oil of high quality, argan oil price rocketed, as did the risk of adulteration. In twenty years, the price of a liter of argan oil has undergone, for the less, a twelve fold increase to reach US\$40 in 2017. Nowadays, the problem has far exceeded the borders of Morocco and is internationally tackled (Momchilova et al., 2016). To the known risk of buying a mixture of vegetable oils and another type of adulteration appeared resulting from the blend of high and low quality argan oil, the result being sold as "high quality argan oil". Several methods have been proposed to detect adulteration in argan oil. Adulteration of argan oil with mineral oil can be easily detected by determination of the unsaponifiable matter content and is therefore uncommon. To detect the fraudulent presence of vegetable oils, a method using the crude oil and based on mid-infrared spectroscopy has been reported; it allows the detection of adulteration with sunflower or soybean oil (Oussama et al., 2012). HPLC-analyzed oil triglyceride profile combined with vaporative light scattering detection can also be used to sign argan oil purity by discriminating it from sunflower, soybean, and olive oil (Salghi et al., 2014). Nevertheless, the dosage of various types of minor components of argan oil used as markers is the most frequently proposed method. Dosage of tocopherols (Matthaüs and Bruehl, 2015; Rueda et al., 2016), sterols (Matthaüs and Bruehl, 2015), hydrocarbons (Ourrach et al., 2012), or ferulic acid (Zougagh et al., 2011) has been suggested. Of particular interest is campesterol, a sterol found in very low concentration in argan oil whereas it is found in high concentration in most vegetable oils. Since campesterol is almost absent in argan oil, its dosage has been selected to be the method of choice to detect argan adulteration with vegetable oils. This method ascertains argan oil purity up to $98 \%$ (Hilali et al., 2007). Adulteration of argan oil with sunflower oil can also be detected using the combination of a voltammetric e-tongue and an e-nose based on metal oxide semiconductor sensors and pattern recognition techniques (Bougrini et al., 2014). Trace element analysis has also been reported as a method to detect argan oil adulteration (Gonzalvez et al., 2010; Mohammed et al., 2013). This area of research is still presently particularly active (Ennoukh et al., 2017). Finally, sensory analysis has been developed to detect adulteration by improper quality argan oil (Matthaüs and Bruehl, 2015). Argan oil quality can be described by trained tasters using positive (nutty, roasty) or negative (Roquefort cheese, rancid, wood-like, bitter, burnt, musty, yeast-like, fusty) descriptors. Improper preparative process inevitably leads to the attribution of negative descriptors (Matthaüs et al., 2010)

Following AOP recommendations, several woman-only cooperatives were founded in the argan forest as early as 1996 to produce high quality argan oil. The choice of a woman-only type of production was dictated to benefit from the traditional knowledge in argan oil preparation hold by women, to empower them and to improve rural woman quality of life by financially rewarding their activity. In addition, an education program was set up to combat illiteracy. Concomitantly, the choice of setting up women's cooperatives in rural areas was not insignificant. All locations selected to implement cooperatives were remote area that had not benefited from technical progress. Consequently, building a cooperative was more than bringing some amount of financial independence to women, it was also bringing new means of communication, new roads, and often a long expected reliable access to electricity. Il also meant that ethnoecological tourists would likely come to visit the cooperative, bringing additional jobs in the ecotourism area. This business model has actively participated to the sustainable development of the argan forest, any other system out of the women's cooperative model presenting the potential to endanger whole argan network by infringement of the AOP recommendations.

Scientific studies were carried out to determine optimum fabrication parameters: fruit drying time (Harhar et al., 2010a), kernel preservation and storage conditions (Harhar et al., 2010b, 2015), harvest date (Harhar et al., 2014), processing (Matthaüs et al., 2010). The results were rapidly implemented within the oil extractive-process used in the cooperatives allowing to ascertain argan oil high quality and its reproducibility. The results were also used as a scientific reference to write the official Moroccan norm (Norme SNIMA, 2003) depicting the required parameters for high quality argan oil. With respect of these recommendations, edible argan oil that was previously known to present low preservation properties was shown to correctly preserve for 2 years (Gharby et al., 2011) and cosmetic argan oil for one year (Gharby et al., 2014). The simultaneous presence of tocopherol, polyphenols and phospholipids in argan oil unsaponifiable matters was found to be responsible for those good preservation profile (Gharby et al., 2012). To certify to consumers that all these rules were respected, a geographic indication was created in 2009 at the instigation of Professor Z. Charrouf by the 
agricultural Ministry with the subsequent help of the Aquitaine region (France) and OriGIn (Organization for an International Geographical Indications Network). All argan oil producers wishing to use this label had to certify that they were following the appropriate specifications.

Once high quality argan oil became produced on a large scale, unsurprisingly, the oil met with an exponentially increasing interest and appreciation in the high-value markets (Europe, North America, Asia). To satisfy this growing market, the kernel supply-chain had to be secure. In the Moroccan rural culture, the argan tree had always been considered a provided by Nature, a tree that did not need to betaken care of. To change the states of mind, a vaster forestation program was officially launched by the Moroccan government. In the early 2000 s, before the beginning of this program the argan forest area was in decline. During year 2005,500 ha were modestly reforested. This area reached 2200 ha in 2009 and 100000 ha on 2017 according to the Haut Commissariat aux Eaux et Forêts et à la Lutte Contre la Désertification and the Minister of agriculture (http://www. leseco.ma/economie/61555-argan-298-mdh-generes-par-l-ex port.html). In addition to symbolic actions aimed at sensibilize the populations by the presence of officials or politicians, plants specificities of the argan tree were presented to the rural population that had never envisioned to "grow" argan trees. Small selected plants germinated under green houses were given to the argan forest dwellers with the responsibility to take care of them (http://www.leconomiste.com/article/1008621souss-arganeraie-la-regeneration-en-marche).

Edible and cosmetic argan oil physiological properties on humans likely result from its unsaturated fatty acid profile and its high content in antioxidative molecules (polyphenols, tocopherols and $\mathrm{CoQ}_{10}$ ) and sterols. Those properties have been frequently reviewed and will not be further detailed here (El Monfalouti et al., 2010; Guillaume and Charrouf, 2011a, b, 2013; Lopez Saez and Alba Sanchez, 2015; Ansuategui and López, 2015). Recently, using a simulated gastrointestinal process, it has been shown that only a minor fraction of argan oil polyphenols is bioavailable for absorption by intestinal cells (Rueda et al., 2017). Therefore, the real physiological impact of polyphenols still needs to be assessed. Nevertheless, benefits of argan oil consumption on dyslipidemia-associated cardiovascular and cerebrovascular complications have been recently confirmed (Batta et al., 2016). New therapeutic benefits of argan oil absorption on human health are still frequently reported and recent cohort studies have evidenced that argan oil consumption presents a preventive effect against key cardiovascular risk factors of metabolic syndrome in knee osteoarthritis patients (Essouiri et al., 2016) and on Knee Osteoarthritis Symptoms (Essouiri et al., 2017).

Efficiency and safety are important matters in the cosmetic domain in which, most of the alleged properties of argan oil initially derived from traditional uses. Some of these properties have been recently confirmed by scientific studies. Hence, the topical application of argan oil has induced an ameliorative effect on skin hydration after 2 months of treatment (Boucetta et al., 2013). The moisturizing/revitalizing effects and anti-hair loss activity of cosmetic argan oil compared to paraffin have been assessed on a panel of volunteers. A significant improvement of the moisturizing quality of the scalp after 3 months of twice a week application has been observed. A significant anti-hair loss activity was observed on the women of the panel. The daily consumption and/or topical application of argan oil has an anti-aging effect on the skin demonstrated by the improvement of skin elasticity (Boucetta et al., 2015).

For the safety purpose, different analyses were performed in 2015. Argan oil, applied as crude oil, can be considered as non-irritant after an application with the help of a semiocclusive patch for 48 consecutive hours (patch test).

For the assessment of sensitizing potential and dermatological compatibility, no significant reaction was observed using the Marzulli-Maibach method, on a panel of 55 healthy adult volunteers. In an independent study performed in 2015, and under the conditions of repeated patch test under occlusion carried out on a panel of 54 healthy subjects, argan oil did not induce skin irritation and did not show any evidence of induced allergic contact dermatitis in human subjects. This study permitted argan oil to claim the mention "Hypoallergenic". In addition, under the conditions of a semi-occlusive photoallergy-phototoxicity study, argan oil was not associated with any photoirritation or phototoxic response. Such affirmation allows to certify the safety of argan oil used in cosmetic

The building of a cooperative in a rural area is an expensive project that succeeded only thank to national or international governmental or non-governmental subsidizations.

\section{Conclusion}

The argan oil project needed 20 years to be implemented. Even though its undeniable success makes the project a frequently used example to illustrate the way to follow in developing countries to increase the value of their natural resources, it must be kept in mind that the price of this success was a daily struggle over many years to convince all the participants and challenge to solve all kind of problems requiring scientific, but more often, psychological and economic knowledge.

\section{References}

Ansuategui M, López V. 2015. Aceite de argán: usos tradicionales, aspectos fitoquímicos, nutricionales y farmacológicos. Rev Fitoterapia 15: 5-19.

Batta FZ, Houssaini TS, Alaoui Sekkouri K, Alaoui H, Dahri S, Alaoui Belghiti $\mathrm{K}$, et al. 2016. Hemodialysis associated dyslipidemia: Effect of Virgin Argan Oil consumption. $J$ Int Res Med Pharm Sci 9: 139-145.

Berrada M. 1972. Étude de la composition de l'huile d'argan. Al Awamia 42: 1-14.

Boucetta KQ, Charrouf Z, Aguenaou H, Derouiche A, Bensouda Y. 2013. Does Argan oil have a moisturizing effect on the skin of post menopausal women? Skin Res Technol 19: 356-357.

Boucetta KQ, Charrouf Z, Aguenaou H, Derouiche A, Bensouda Y. 2015. The effect of dietary and/or cosmetic argan oil on postmenopausal skin elasticity. Clin Interv Aging 10: 339-349.

Bougrini M, Tahri K, Haddi Z, Saidi T, El Bari N, Bouchikhi B. 2014. Detection of adulteration in argan oil by using an electronic nose and a voltametric electronic tongue. J Sensors 245831/1-245831/ $1011 \mathrm{p}$.

Charrouf Z, El Hamchi H, Mallia S, Licitra G, Guillaume D. 2006. Influence of roasting and seed collection on argan oil odorant composition. Nat Prod Commun 1: 399-404. 
Charrouf Z, Guillaume D. 2010. Should the amazigh diet (regular and moderate argan-oil consumption) have a beneficial impact on human health? Crit Rev Food Sci Nutr 50: 473-477.

El Monfalouti H, Guillaume D, Denhez C, Charrouf Z. 2010. Therapeutic potential of argan oil - A review. J Pharm Pharmacol 62: $1669-1675$

Ennoukh F, Bchitou R, Mohammed F, Guillaume D, Harhar H, Bouhaouss A. 2017. Study of the effects of extraction methods on argan oil quality through its metal content. Ind Crops Prod 109: 182-184.

Essouiri J, Abourazzak FE, Lazrak F, Najdi A, Benaicha N, Harzy T, et al. 2016. Efficacy of argan oil on metabolic syndrome in a Moroccan knee osteoarthritis population. Curr Rheumatol Rev 12: 326-329.

Essouiri J, Harzy T, Benaicha N, Errasfa M, Abourazzak FE. 2017. Effectiveness of argan oil on knee osteoarthritis symptoms: a randomized controlled clinical trial. Curr Rheumatol Rev. In press. DOI: 10.2174/1573397113666170710123031.

Gharby S, Harhar H, Guillaume D, Haddad A, Matthäus B, Charrouf Z. 2011. Oxidative stability of edible argan oil: a two-year period study. LWT-Food Sci Technol 44: 1-8.

Gharby S, Harhar H, Guillaume D, Haddad A, Charrouf Z. 2012. The origin of virgin argan oil's high oxidative stability unraveled. Nat Prod Commun 7: 621-624.

Gharby S, Harhar H, Kartah B, Guillaume D, ChafchaouniMoussaoui I, Charrouf Z. 2014. Oxidative stability of cosmetic argan oil: a one-year study. J Cosmetic Chem 65: 81-88.

Gonzalvez A, Armenta S, de la Guardia M. 2010. Adulteration detection of argan oil by inductively coupled plasma optical emission spectrometry. Food Chem 121: 878-886.

Guillaume D, Charrouf Z. 2011a. Argan oil. Monograph. Alter Med Rev 6: 275-278.

Guillaume D, Charrouf Z. 2011b. Argan oil and other argan products: Use in dermocosmetology. Eur J Lipid Sci Technol 113: 403-408.

Guillaume D, Charrouf Z. 2013. Argan oil for nutritional and skin care applications. H\&PC Today Household and Personal Care 8: 28-30.

Guillaume D, CharroufZ. Functional food and sustainable development once met in the argan forest: The tale of the argan oil. In: Kristbergsson K, Ötles S, eds. Functional Properties of Traditional Foods, Integrating Food Science and Engineering Knowledge Into the Food Chain, Vol 12. New York: Springer, 2016, pp. 309-320.

Harhar H, Gharby S, Kartah B, El Monfalouti H, Guillaume D, Charrouf Z. 2010a. Long argan fruit drying time is detrimental for argan oil quality. Nat Prod Commun 5: 1799-1802.

Harhar H, Gharby S, Guillaume D, Charrouf Z. 2010b. Effect of argan kernel storage conditions on argan oil quality. Eur J Lipid Sci Technol 112: 915-920.

Harhar H, Gharby S, Kartah B, El Monfalouti H, Guillaume D, Charrouf Z. 2011. Influence of argan kernel roasting-time on virgin argan oil composition and oxidative stability. Plant Foods Hum Nutr 66: 163-168.

Harhar H, Gharby S, Kartah B, Pioch D, Guillaume D, Charrouf Z. 2014. Effect of harvest date of Argania spinosa fruits on argan oil quality. Ind Crops Prod 56: 156-159.

Harhar H, Gharby S, Guillaume D, Bouzoubaa Z, Kartah B, Charrouf Z. 2015. Influence of argan fruit peel on the quality and oxidative stability of argan oil on prolonged storage. Emirates J Food Agric 27: $522-526$.
Hilali M, Charrouf Z, El Aziz Soulhi A, Hachimi L, Guillaume D. 2005. Influence of origin and extraction method on argan oil physico-chemical characteristics and composition. J Agric Food Chem 53: 2081-2087.

Hilali M, Charrouf Z, El Aziz Soulhi A, Hachimi L, Guillaume D. 2007. Detection of argan oil using quantitative campeserol GCanalysis. J Am Oil Chemist Soc 84: 761-764.

Kenny L, De Zborowski I. Biologie de l'arganier. In: Atlas de l'arganier et de l'arganeraie. Rabat, Morocco : Hassan II IAV (ed), 2007, p. 190.

Lopez Saez JA, Alba Sanchez F. 2015. Ecología, etnobotánica y etnofarmacología del argán (Argania spinosa). Boletín Latino americano y del Caribe de Plantas Medicinales y Aromáticas 8: 323-341.

Matthaüs B, Bruehl L. 2015. Quality parameters for the evaluation of cold-pressed edible argan oil. J Verbrauch Lebensm 10: 143-154.

Matthaüs B, Guillaume D, Gharby S, Haddad A, Harhar H, Charrouf Z. 2010. Effect of processing on the quality of edible argan oil. Food Chem 120: 426-432.

Mohammed FAE, Bchitou R, Bouhaouss A, Gharby S, Harhar H, Guillaume D, et al. 2013. Can the dietary content of virgin oils really be used for adulteration detection? Food Chem 136: 105-108.

Momchilova SM, Taneva SP, Dimitrova RD, Totseva IR, Antonova DV. 2016. Evaluation of authenticity and quality of argan oilsold on the BulgarianMarket. Riv Ital Sostanze Gr 93: 95-103.

Mounir F, Jourrane M, Sabir M. 2015. Analyse basée télédétection pour la révision de la carte de répartition des peuplements a arganeraie et comparaison diachronique de sa dynamique spatiotemporelle. In: Actes du $3^{\mathrm{e}}$ congrès International de l'Arganier, agadir 17-19 décembre 2015. Page 36.

Norme SNIMA. 2003. Service de normalisation industrielle marocaine (Snima), Corps gras d'origine animale ou végétale - Huiles d'argan. Spécification. Norme marocaine NM 08.5.090, Rabat.

Ourrach I, Rada M, Perez-Camino MC, Benaissa M, Guinda A. 2012. Detection of argan oil adulterated with vegetable oils: new markers. Grasas Aceites 63: 355-364.

Oussama A, Elabadi F, Devos O. 2012. Analysis of Argan Oil Adulteration Using Infrared Spectroscopy. Spectrospec Lett 45: 458-463.

Rueda A, Samaniego-Sanchez C, Olalla M, Gimenez R, CabreraVique C, Seiquer I, et al. 2016. Combination of analytical and chemometric methods as a useful tool for the characterization of extra virgin argan oil and other edible virgin oils. Role of polyphenols and tocopherols. J AOAC Internat 9: 489-494.

Rueda A, Cantarero S, Seiquer I, Cabrera-Vique C, Olalla M. 2017. Bioaccessibily of individual phenolic compounds in extra virgin argan oil after simulated gastrointestinal process. LWT-Food Sci Technol 75: 466-472.

Salghi R, Armbruster W, Schwack W. 2014. Detection of argan oil adulteration with vegetable oils by high-performance liquid chromatography-evaporative light scattering detection. Food Chem 153: 387-392.

Venegas C, Cabrera-Vique C, García-Corzo L, Escames G, AcunaCastroviejo D, Carlos Lopez L. 2011. Contents in virgin argan oils: Comparison with other edible vegetable oils. J Agric Food Chem 59: 12102-12108.

Zougagh M, Salghi R, Dhair S, Rios A. 2011. Nanoparticle-based assay for the detection of virgin argan oil adulteration and its rapid quality evaluation. Anal Bioanal Chem 399: 2395-2405.

Cite this article as: Charrouf Z, Guillaume D. 2018. The argan oil project: going from utopia to reality in 20 years. $O C L 25(2)$ : D209. 